Original

\title{
Toxicity and Paralytic Shellfish Poison Composition of Three Species of Bivalves Collected in Ibaraki Prefecture, Japan
}

(Received October 30, 1998)

\author{
Ritsuko Murakami*1, Kazunori Yamamoto*1 and Tamao Noguchi*2 \\ (*1 Ibaraki Prefectural Institute of Public Health: 993-2, Kasaharacho, Mito 310-0852, Japan; \\ ${ }^{* 2}$ Faculty of Fisheries, Nagasaki University: 1-14, Bunkyo-machi, Nagasaki 852-8131, Japan)
}

\begin{abstract}
Three species of bivalves (mussel, hard clam, and surf clam) were collected in 1990-98 in Ibaraki Prefecture, Japan, and assayed for toxicity and composition of paralytic shellfish poison (PSP). All the species of bivalves were found to be toxic every or every other year; they became toxic in March or early April and nontoxic in May. Their digestive glands showed the highest toxicity scores, ranging from 100 to $300 \mathrm{MU} / \mathrm{g}$. Irrespective of the species and parts ("muscle" and "visceral" parts), PSP was composed almost exclusively of protogonyautoxins (PXs)1,2 and gonyautoxins (GTXs)1-4. The PSP composition profile, however, was speciesspecific and differed between the two parts in each species. The ratio of N1-OH toxins (GTX 1, GTX4) to N1-H toxins (GTX2, GTX3) differed significantly among the species. The ratio also differed between the two parts of both clams, though not in the mussel. This suggested that species- and organ-specific metabolism could have taken place in the viscera.

In each species, on the other hand, the ratio of $\alpha$-epimer (GTX1) to $\beta$-epimer (GTX4) at position $\mathrm{C} 11$ tended to increase up to the equilibrium point of $3: 1$.
\end{abstract}

Key words: toxicity; paralytic shellfish poison (PSP); bivalves; mouse assay; HPLC

Paralytic shellfish poison (PSP) infestation of bivalves by toxic dinoflagellates such as Alexandrium spp. poses serious problems to public health and the fishery industry all over the world. A number of studies have been carried out on biological aspects of causative plankton, infestation mechanisms of bivalves, chemistry of PSP, etc.

Ibaraki Prefecture has a long coast line of some $180 \mathrm{~km}$, with an abundance of marine products, especially shellfish. To protect consumers from PSP and/or other poisonings, some bivalves are periodically collected from main bivalve-producing areas and assayed for toxicity. However, from a food hygiene point of view, it is still necessary to elucidate the mechanisms of toxification and detoxification of bivalves. Since PSP composition assay may cast light on this problem, in the present study, three species of bivalves were assayed for toxicity and PSP composition, from 1990 through 1998.

\section{Materials and Methods}

\section{Materials}

The mussel Mytilus edulis and hard clam $\mathrm{Me}$ retrix lamarckii were collected mostly from Kashima, Ibaraki Pref., from 1990 through 1998 and the surf clam Pseudocardium sachalinensis from Kujihama, Ibaraki Pref., from 1993 through 1998 (Fig. 1). In 1996, some specimens of hard and surf clams were collected simultaneously in the same net at Kashima or Kujihama.

The digestive gland was excised from each bivalve (300-500 mussels, 100-200 hard clams and 30-50 surf clams), combined and assayed for toxicity. The whole edible part of the bivalves was also assayed for toxicity. The digestive gland was also analyzed for PSP composition. In addition, some specimens of both clams were dissected into anatomical parts (refer to Table 2), which were assayed for toxicity. Other specimens of each bivalve were divided into the visceral and muscular parts, which were 


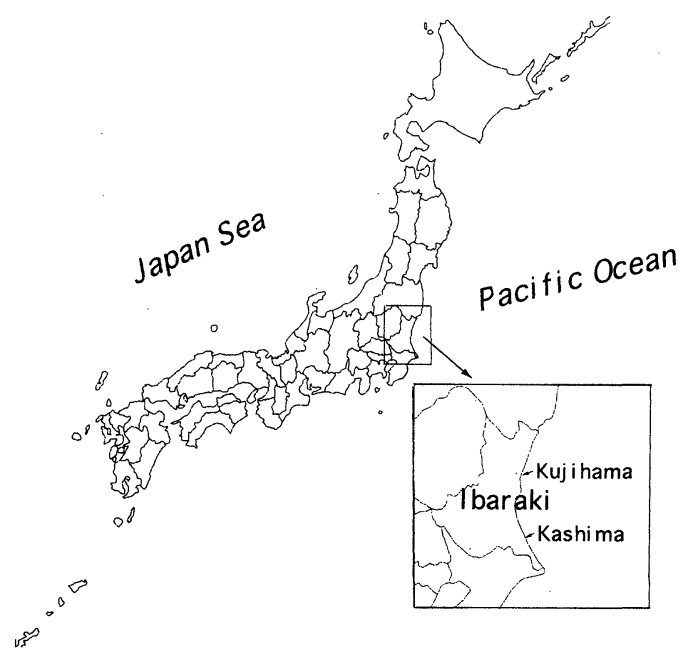

Fig. 1. Sampling sites of bivalves

separately analyzed for PSP composition, as described later.

\section{Reagents}

All solvents and reagents were of analytical or LC grade. Gonyautoxin (GTX) 1-4 mixture was prepared from PSP-infested scallop Patinopecten yessoensis by the method of Noguchi et al ${ }^{11}$. Neosaxitoxin (neoSTX) and saxitoxin (STX) mixture was prepared from a xanthid crab Zosimus aeneus by the method of Daigo et $a l^{2}$. They were used as PSP standards.

\section{Apparatus and chromatographic conditions}

HPLC system: A $300 \mathrm{~mm} \times 6 \mathrm{~mm}$ (i.d.) silica ODS column (YMC AM 3-14, Yamamura Kaga$\mathrm{ku}$ ), a high-pressure pump (Hitachi L-7100) and a syringe loading sample injector (Reodyne 7125) were used at room temperature.

Mobile phase: The mobile phase was a mixture of $0.05 \mathrm{~mol} / \mathrm{L}$ phosphate buffer ( $\mathrm{pH} 7.0)$ containing $2 \mathrm{mmol} / \mathrm{L}$ heptanesulfonic acid and methanol at $99: 1(\mathrm{v} / \mathrm{v})$ for GTXs and at $75: 25$ $(\mathrm{v} / \mathrm{v})$ for STXs.

Fluorometric detector: A fluoromonitor (Hitachi F1080) was operated at $336 \mathrm{~nm}$ for excitation and $390 \mathrm{~nm}$ for emission.

Post column reaction: A double-headed reaction pump (Nihon Seimitsu Kagaku) was used for delivering two reagents: (A) $0.05 \mathrm{~mol} / \mathrm{L}$ periodic acid, and (B) $0.2 \mathrm{~mol} / \mathrm{L} \mathrm{KOH}$ plus $1 \mathrm{~mol} / \mathrm{L}$ ammonium formate in $50 \%$ formamide. Reagents (A) and (B) were delivered at a flow rate of $0.5 \mathrm{~mL} / \mathrm{min}$, through $10 \mathrm{~m}$ Teflon tubing of 0.25 $\mathrm{mm}$ i.d. in a dry oven (Nihon Seimitsu Kagaku) at $65^{\circ} \mathrm{C}$.

\section{Assay of toxicity}

Toxicity of PSP in the digestive gland and whole edible part of bivalves was determined by means of the Japanese official method ${ }^{3)}$, using ddY strain male mice weighing 19-21 g. One mouse unit (MU) is defined as the amount of toxin which kills a mouse within 15 min after intraperitoneal injection.

\section{Determination of PSP composition}

PSP composition of the digestive gland and other parts from bivalves was determined as follows. Three volumes of $80 \% \mathrm{EtOH}$ adjusted to $\mathrm{pH} 3.5$ with $1 \mathrm{~mol} / \mathrm{L}$ acetic acid was added to $10 \mathrm{~g}$ of a sample and homogenized. The homogenate was centrifuged at $3,000 \times \mathrm{g}$ for $15 \mathrm{~min}$. This procedure was repeated two more times. The supernatants obtained were combined and concentrated under reduced pressure. After having been defatted with dichloromethane, the solution was applied to a cartridge column of Sep-Pak C18 (Waters, USA). The eluate was analyzed for PSP by an HPLC method with a fluorometric detector ${ }^{4}$. In order to determine the low-toxicity components (PXs), the eluate was hydrolyzed with $0.1 \mathrm{~mol} / \mathrm{L}$ hydrochloric acid in boiling water for $15 \mathrm{~min}$ according to the AOAC method ${ }^{5)}$. The PX content was calculated by subtracting the value for the corresponding GTX before hydrolysis from that after it.

\section{Results}

Table 1 shows the toxicity values of the three bivalves.

The bivalves tested were toxified every or every other year from 1990 through 1998. As a whole, they became toxic in late March or early April, showed the highest toxicity score mostly in April, and then became nontoxic in middle or late May. In 1998, the highest toxicity level of the mussel was observed in early March. The mussel retained its toxicity for the longest period among the three species. Difference in seasonal changes of toxicity were found be- 
Table 1. Toxicity in the Digestive Gland of Three Bivalves

\begin{tabular}{|c|c|c|c|c|c|}
\hline \multicolumn{2}{|c|}{ Mussel Mytilus edulis } & \multicolumn{2}{|c|}{ Hard clam Meretrix Iamarckii } & \multicolumn{2}{|c|}{ Surf clam Pseudocardium sachalinensi } \\
\hline $\begin{array}{l}\text { Date of collection } \\
\text { (Year/Month/Day) }\end{array}$ & $\begin{array}{l}\text { Toxicity } \\
\text { (MU/g) }\end{array}$ & $\begin{array}{l}\text { Date of collection } \\
\text { (Year/Month/Day) }\end{array}$ & $\begin{array}{l}\text { Toxicity } \\
\text { (MU/g) }\end{array}$ & $\begin{array}{l}\text { Date of collection } \\
\text { (Year/Month/Day) }\end{array}$ & $\begin{array}{l}\text { Toxicity } \\
\text { (MU/g) }\end{array}$ \\
\hline $1990 / 4 / 10$ & 2.9 (ND) & $1990 / 4 / 26$ & 5.4 (ND) & & \\
\hline $4 / 24$ & 12.9 (ND) & $5 / 23$ & 7.5 (ND) & & \\
\hline $5 / 24$ & 12.5 (ND) & $6 / 21$ & ND (ND) & & \\
\hline $1991 / 3 / 5$ & $\mathrm{ND}(\mathrm{ND})$ & $1991 / 4 / 23$ & $3.2(\mathrm{ND})$ & & \\
\hline $4 / 17$ & $299.2(244.6)$ & $5 / 10$ & 5.5 (ND) & & \\
\hline $5 / 14$ & $54.4(8.8)$ & $6 / 14$ & $\mathrm{ND}(\mathrm{ND})$ & & \\
\hline $6 / 12$ & $2.5(\mathrm{ND})$ & & & & \\
\hline $1992 / 3 / 19$ & $\mathrm{ND}(\mathrm{ND})$ & $1992 / 5 / 6$ & ND (ND) & & \\
\hline $4 / 20$ & 2.5 (ND) & $6 / 3$ & ND (ND) & & \\
\hline $5 / 18$ & ND (ND) & & & & \\
\hline $1993 / 2 / 23$ & ND (ND) & $1993 / 4 / 3$ & $10.3(2.2)$ & $1993 / 4 / 13$ & 5.8 (ND) \\
\hline $3 / 29$ & $166.9(58.4)$ & $4 / 8$ & $36.5(2.1)$ & $4 / 19$ & 3.0 (ND) \\
\hline $4 / 12$ & $231.7(54.4)$ & $4 / 14$ & $16.4(2.2)$ & & \\
\hline $5 / 10$ & $19.6(2.0)$ & $4 / 22$ & 13.9 (ND) & & \\
\hline $5 / 17$ & $36.4(2.8)$ & $5 / 13$ & 2.9 (ND) & & \\
\hline $5 / 25$ & $5.8(\mathrm{ND})$ & & & & \\
\hline $1994 / 2 / 28$ & ND (ND) & $1994 / 3 / 31$ & ND (ND) & $1994 / 4 / 26$ & $143.7(25.8)$ \\
\hline $3 / 28$ & $48.3(13.0)$ & $4 / 12$ & $39.5(2.6)$ & $5 / 19$ & $7.7(2.2)$ \\
\hline $4 / 26$ & $50.9(8.3)$ & $4 / 18$ & $59.7(5.4)$ & $5 / 26$ & 2.1 (ND) \\
\hline $5 / 11$ & 3.2 (ND) & $5 / 11$ & 2.4 (ND) & & \\
\hline $1995 / 3 / 16$ & 2.0 (ND) & $1995 / 3 / 22$ & 2.4 (ND) & $1995 / 4 / 13$ & 2.8 (ND) \\
\hline $4 / 17$ & $29.2(5.4)$ & $4 / 21$ & $15.3(2.9)$ & $4 / 20$ & 8.4 (ND) \\
\hline \multirow[t]{3}{*}{$5 / 15$} & 4.5 (ND) & $4 / 25$ & $107.3(5.8)$ & $4 / 25$ & 9.6 (ND) \\
\hline & & $5 / 9$ & 10.5 (ND) & $4 / 28$ & 6.2 (ND) \\
\hline & & & & $5 / 8$ & 2.2 (ND) \\
\hline $1996 / 3 / 22$ & $151.4(67.4)$ & $1996 / 3 / 22$ & 2.7 (ND) & $1996 / 3 / 28$ & $5.9(2.1)$ \\
\hline $5 / 17$ & $20.7(3.3)$ & $3 / 29$ & $46.5(2.8)$ & $4 / 4$ & *21.4 (3.2) \\
\hline \multirow[t]{7}{*}{$6 / 3$} & 7.9 (ND) & $4 / 4$ & *23.7 (ND) & $4 / 9$ & $* 21.9(2.8)$ \\
\hline & & $4 / 9$ & *34.8 (ND) & $4 / 10$ & *32.1 (3.9) \\
\hline & & $4 / 10$ & *36.0 (3.0) & $4 / 16$ & $212.1(7.9)$ \\
\hline & & $4 / 15$ & $52.2(2.5)$ & $4 / 23$ & *19.2 (ND) \\
\hline & & $4 / 23$ & *34.3 (2.2) & $4 / 30$ & $14.0(2.7)$ \\
\hline & & $5 / 1$ & $46.1(3.0)$ & $5 / 1$ & $5.6(\mathrm{ND})$ \\
\hline & & $5 / 13$ & 12.8 (ND) & $5 / 13$ & 6.7 (ND) \\
\hline $1997 / 3 / 7$ & 2.0 (ND) & $1997 / 4 / 11$ & $\mathrm{ND}(\mathrm{ND})$ & $1997 / 4 / 11$ & $\mathrm{ND}$ (ND) \\
\hline $4 / 10$ & 2.2 (ND) & $5 / 2$ & ND (ND) & $4 / 17$ & ND (ND) \\
\hline $4 / 24$ & ND (ND) & & & $5 / 1$ & ND (ND) \\
\hline $5 / 9$ & $\mathrm{ND}(\mathrm{ND})$ & & & $5 / 16$ & $\mathrm{ND}(\mathrm{ND})$ \\
\hline $5 / 23$ & 6.1 (ND) & & & & \\
\hline $1998 / 3 / 3$ & $107.8(43.3)$ & $1998 / 3 / 9$ & ND (ND) & $1998 / 3 / 9$ & 3.8 (ND) \\
\hline $3 / 18$ & $51.2(15.7)$ & $3 / 12$ & 3.8 (ND) & $3 / 11$ & 4.3 (ND) \\
\hline $3 / 30$ & $24.2(6.2)$ & $3 / 28$ & $21.2(2.2)$ & $3 / 16$ & 2.3 (ND) \\
\hline $4 / 17$ & $5.1(2.0)$ & $4 / 6$ & $5.4(\mathrm{ND})$ & $4 / 13$ & 7.5 (ND) \\
\hline $4 / 27$ & $3.4(2.0)$ & $5 / 15$ & $\mathrm{ND}(\mathrm{ND})$ & $5 / 14$ & $\mathrm{ND}$ (ND) \\
\hline $5 / 13$ & 2.2 (ND) & & & $5 / 15$ & ND (ND) \\
\hline $5 / 27$ & 2.2 (ND) & & & & \\
\hline $6 / 12$ & ND (ND) & & & & \\
\hline
\end{tabular}

( ): Toxicity of whole edible part; MU/g. ND: not detected; less than $2.0 \mathrm{MU} / \mathrm{g}$

* Hard clam or surf clam collected at the same time and in the same net. 
tween the hard clam and surf clam in 1996 (Fig. 2). The hard clam maintained its toxicity at roughly the same level over the period covered, whereas the toxicity of the surf clam increased sharply in mid April.

The digestive gland showed the highest toxicity score in all three species, ranging from 100 to $300 \mathrm{MU} / \mathrm{g}$, i.e., $299.2 \mathrm{MU} / \mathrm{g}$ in mussel, 107.3 $\mathrm{MU} / \mathrm{g}$ in hard clam and $212.1 \mathrm{MU} / \mathrm{g}$ in surf clam. In the case of the whole edible part, the highest scores were $244.6 \mathrm{MU} / \mathrm{g}$ in mussel, 5.8 $\mathrm{MU} / \mathrm{g}$ in hard clam, and $25.8 \mathrm{MU} / \mathrm{g}$ in surf clam. Hard and surf clams were cut into various parts, which were assayed separately for toxicity; the highest toxicity was found in digestive gland, followed by intestine, gill, mantle (Table 2). In

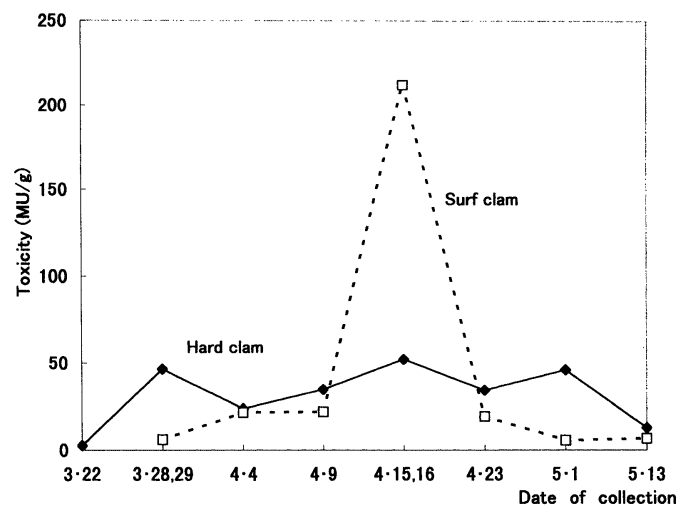

Fig. 2. Seasonal changes in toxicity of the digestive gland from hard clam and surf clam in 1996 surf clam, the crystalline style exhibited the second highest toxicity and the gonad showed some toxicity.

HPLC analysis showed that in all three bivalves the toxin was composed almost exclusively of GTX1, GTX2, GTX3, GTX4, PX2 and a small amount of PX1, whereas STXs were hardly detected (Figs. 3 and 4).

The PSP composition profiles of the digestive gland widely differed among the three species, especially in the ratio of $\mathrm{N} 1-\mathrm{OH}$ carbamate toxins (GTX1, GTX4) to N1-H carbamate toxins (GTX2, GTX3). This was also the case between hard and surf clam specimens collected from the same site at the same time. In the mussel, epimeric N1-OH toxins (GTX1, GTX4) whose total amount was 69.7-87.6 mol\%, were predominant. This was also the case with surf clam, in which GTX1+GTX4 accounted for 35.5-79.8 mol\%. The ratio of $\mathrm{N} 1-\mathrm{OH}$ toxins to $\mathrm{N} 1-\mathrm{H}$ toxins in this clam was lower than in the mussel; the mean of $\mathrm{N} 1-\mathrm{H}$ toxins was $20.1 \mathrm{~mol} \%$ in the former and $12.5 \mathrm{~mol} \%$ in the latter. In hard clam, the $\mathrm{N} 1-\mathrm{H}$ carbamate toxin GTX3 was increased to the mean of $41.4 \mathrm{~mol} \%$. In mussel, the amount of PX1, 2 was $8-14 \mathrm{~mol} \%$ at the beginning of the toxification, and decreased to $0.7-4.2 \mathrm{~mol} \%$ at the end of it. In hard and surf clams, such seasonal changes of PX 1,2 were not clear, and the level remained at $10-20 \mathrm{~mol} \%$ through the period covered.

The ratio of N1-OH toxins to $\mathrm{N} 1-\mathrm{H}$ toxins also

Table 2. Anatomical Distribution of PSP in Hard Clam and Surf Clam

\begin{tabular}{|c|c|c|c|c|}
\hline \multirow{3}{*}{ Anatomical part } & \multicolumn{4}{|c|}{ Toxicity (MU/g) } \\
\hline & \multicolumn{2}{|c|}{ Hard clam } & \multicolumn{2}{|c|}{ Surf clam } \\
\hline & ('94/4/18) & ('95/4/25) & ('94/4/26) & ('96/4/16) \\
\hline Digestive gland & 59.7 & 107.3 & 143.7 & 212.1 \\
\hline Crystalline style & & & & 85.3 \\
\hline Intestine & 9.5 & $\mathrm{ND}$ & 64.1 & 14.6 \\
\hline Gonad & & & & 7.3 \\
\hline Gill & 3.6 & $\mathrm{ND}$ & 9.2 & 4.1 \\
\hline Mantle & 2.0 & $\mathrm{ND}$ & 8.9 & 3.6 \\
\hline Siphon & 2.0 & ND & 3.1 & 3.0 \\
\hline Foot & 2.0 & ND & 3.1 & 2.5 \\
\hline Adductor muscle & 2.0 & $\mathrm{ND}$ & 2.1 & 2.3 \\
\hline Other muscles & 2.8 & ND & 4.1 & 3.4 \\
\hline
\end{tabular}

ND: not detected; less than $2.0 \mathrm{MU} / \mathrm{g}$ 


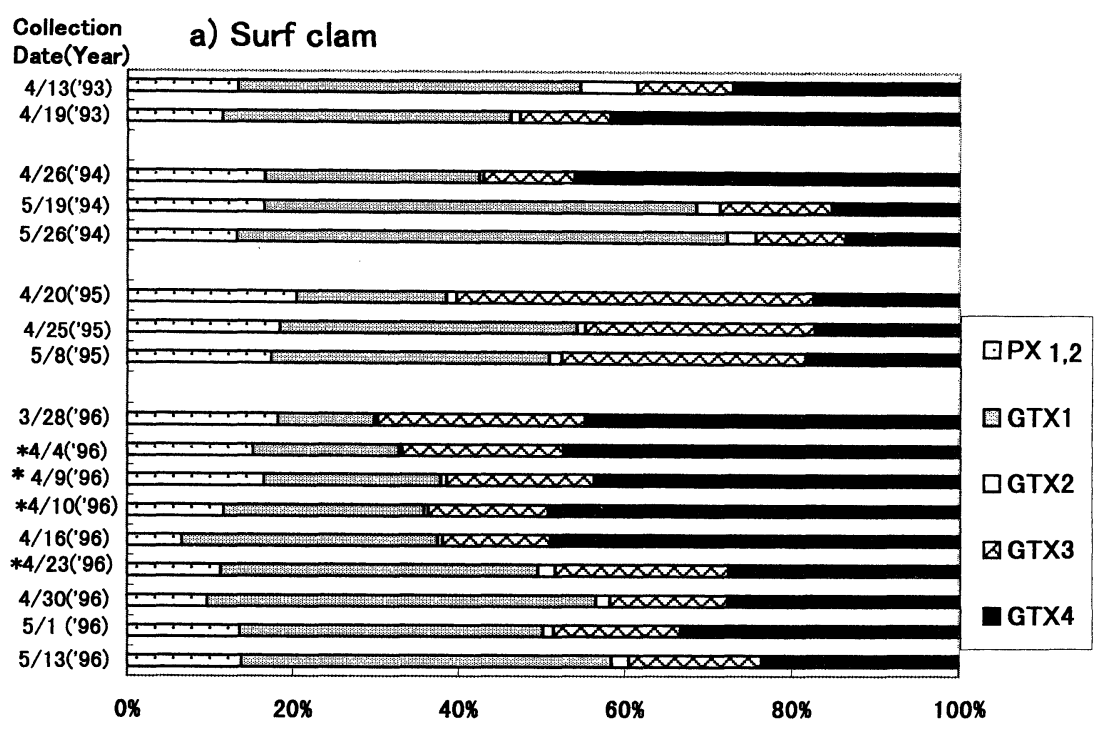

b) Hard clam

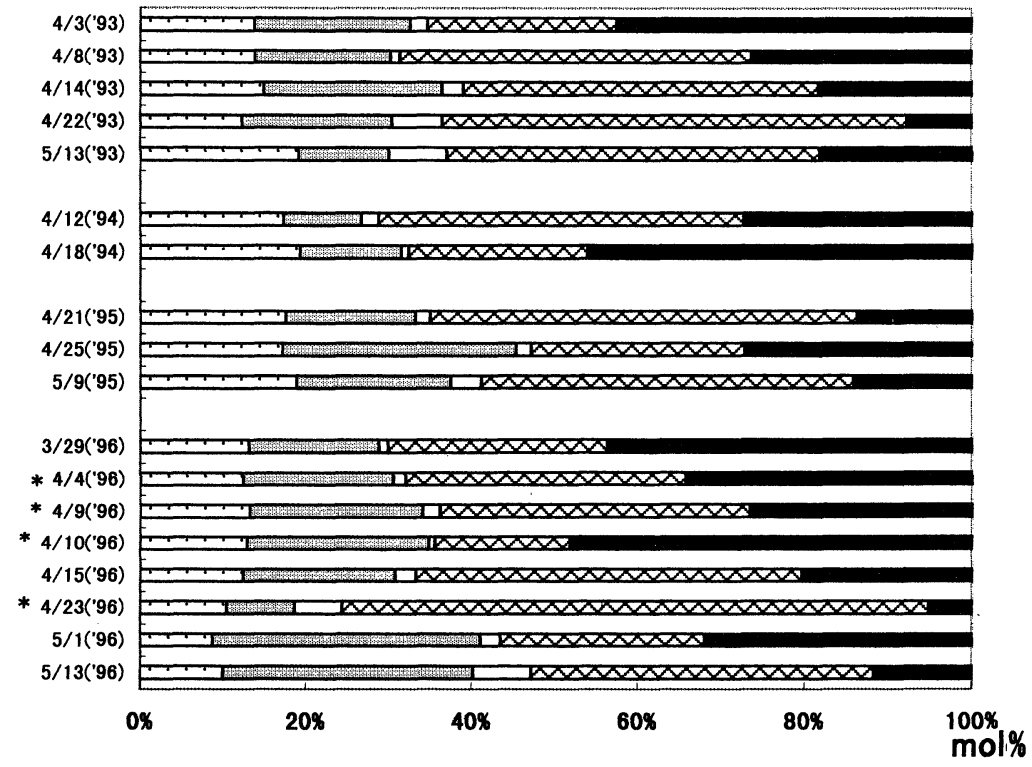

Fig. 3. PSP composition of the digestive gland from surf clam and hard clam collected from 1993 through 1996

* Specimens collected in the same net at the same time.

differed between the viscera and muscle parts of each clam, the ratio in the former being much less than in the latter (Fig. 5).

Epimerization of $\mathrm{OSO}_{3}^{-}$at the $\mathrm{C}-11$ position (Fig. 6) occurs in some PSP components during the toxification and detoxification processes of bivalves. Figure 7 shows seasonal changes in the ratio of GTX2 ( $\alpha$-epimer) to GTX3 ( $\beta$-epimer) and GTX1 ( $\alpha$-epimer) to GTX4 ( $\beta$-epimer) of the three bivalves collected in 1996. The GTX1/ GTX4 ratio tended to increase up to $3: 1$, while the GTX2/GTX3 ratio showed a rather small increase in all three species.

In the edible part (excluding the digestive gland) of the mussels collected in 1998, GTXs $(1,4)$ accounted for $85.5-91.3 \mathrm{~mol} \%$ of the total, 

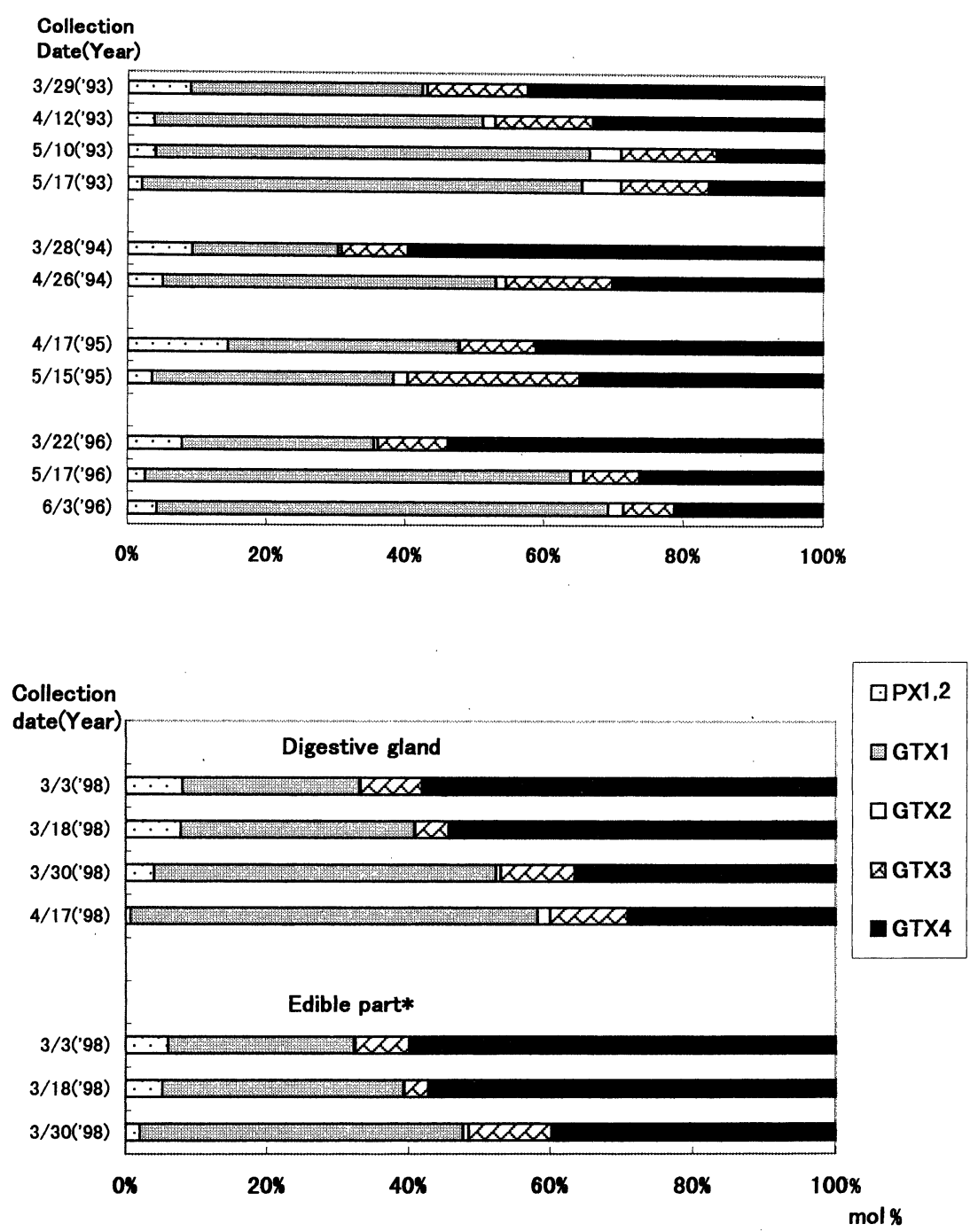

Fig. 4. PSP composition of the digestive gland from mussel

Top: from 1993 through 1996

Bottom: in 1998

Edible part*: edible part excluding digestive gland

with a seasonal decrease of PX 1,2 and a gradual epimerization of $\operatorname{GTX} 4(\beta)$ to $\operatorname{GTX} 1(\alpha)$. These results were essentially the same as in the digestive gland: the values of the ratio of GTX1 to GTX4 in the digestive gland and edible part were 0.43 and 0.44 on March 3 and gradually increased to 0.61 and 0.60 on March 18, and 1.2 and 1.3 on March 30 , respectively (Fig. 8).

\section{Discussion}

The present study demonstrated that all the bivalve species were toxified almost every year in Ibaraki Prefecture. Seasonal changes in toxicity differed markedly among bivalves; e.g., in 1996, the surf clam was toxified abruptly in mid April, whereas the hard clam showed roughly the same level of toxicity throughout. The causative organism is assumed to be a toxic dinoflagellate, Alexandrium tamarense, which appears in the region every spring. This dinoflagellate always produces essentially the same profile of PSP, with some geographical variation ${ }^{6}$. The 


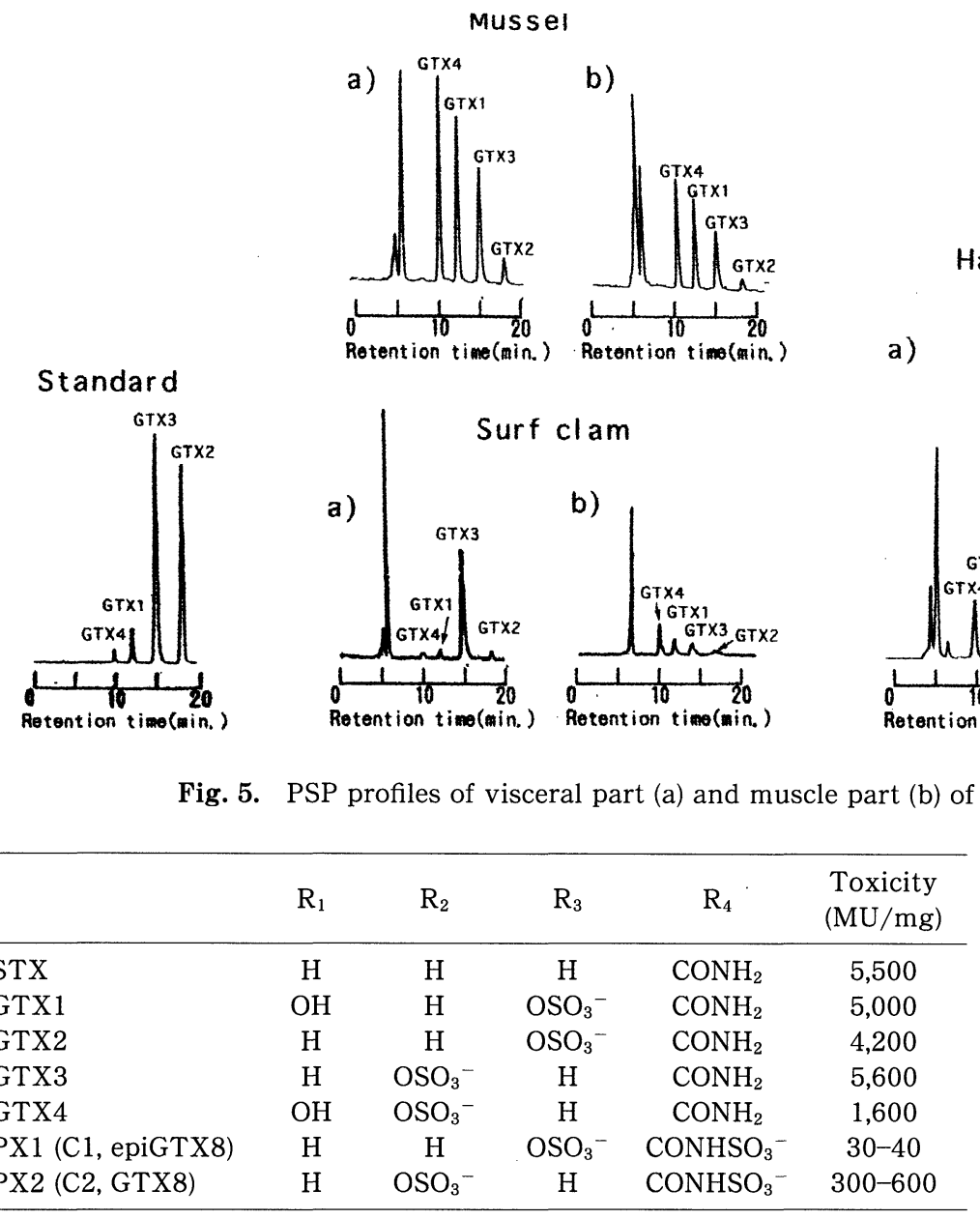

STX: saxitoxin; GTX: gonyautoxin; PX: protogonyautoxin

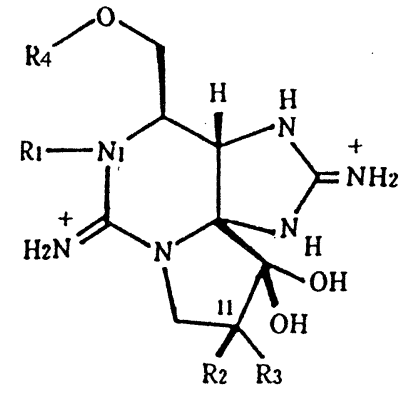

Fig. 6. Structure of PSP

PSP composition of a bivalve could reflect that of the causative dinoflagellate, as far as major components such as GTX1-4 are concerned. In this study, however, species-specific differences in PSP composition profile were recognized among the three bivalves and even between the two types of clams collected simultaneously from the same site. In particular, the ratio of GTX2,3 (N1-H carbamate toxins) to GTX1,4 (N1$\mathrm{OH}$ carbamate toxins) was much higher in both clams than in mussel. On the other hand, the toxin profile clearly differed between the visceral and muscle parts of each clam, though not in the mussel. These results suggested that the structures of PSP are changed or modified in the viscera through species-specific metabolism.
It is accepted that dinoflagellates produce $\beta$ epimers such as GTX3, 4, and PX27). Such $\beta$ epimers of PSP ingested by shellfish could gradually be transformed to chemically more stable $\alpha$-epimers to attain the equilibrium point, $\alpha: \beta \fallingdotseq$ $3: 1$. Therefore, the $\alpha: \beta$ ratio (GTX1/GTX4) in a bivalve may provide information as to the lapse of time after infestation by toxic plankton. The $\alpha: \beta$ ratio of GTX2/GTX3, however, showed a much smaller increase in all the species.

In 1998, the mussel developed high toxicity much earlier than in the other years covered. Nevertheless, the PSP composition predominantly featured GTX1, 4 and exhibited gradual epimerization of $\operatorname{GTX} 4(\beta)$ to $\operatorname{GTX} 1(\alpha)$, demonstrating that in 1998 , the mussel was toxified by 


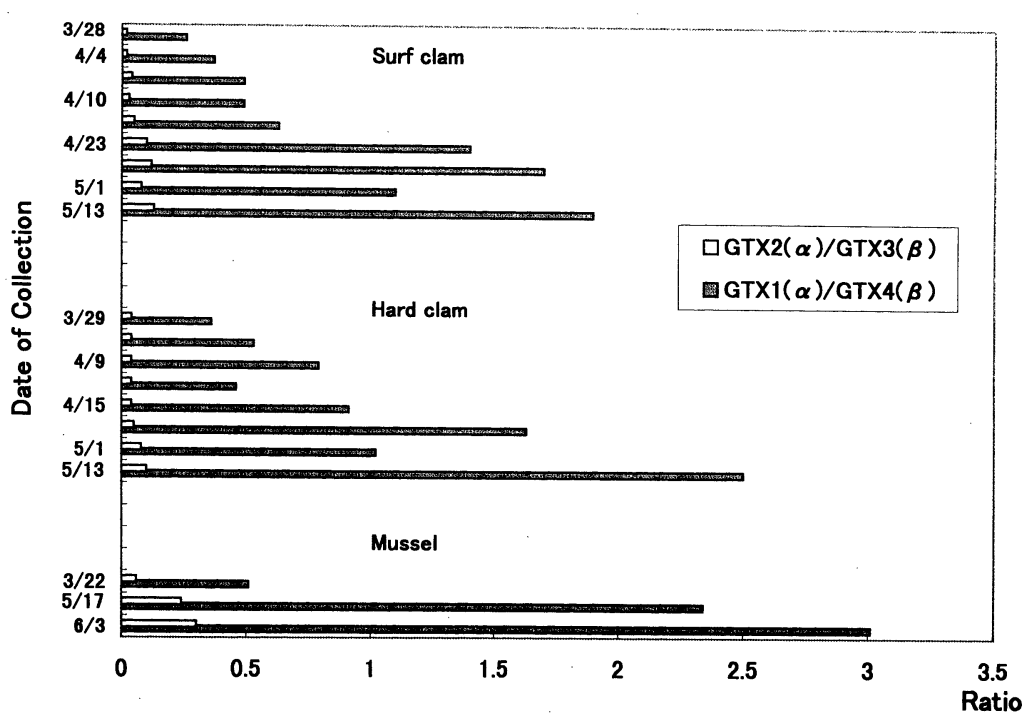

Fig. 7. Seasonal changes in $\alpha$ - to $\beta$-epimer ratio of GTXs in three bivalves collected in 1996

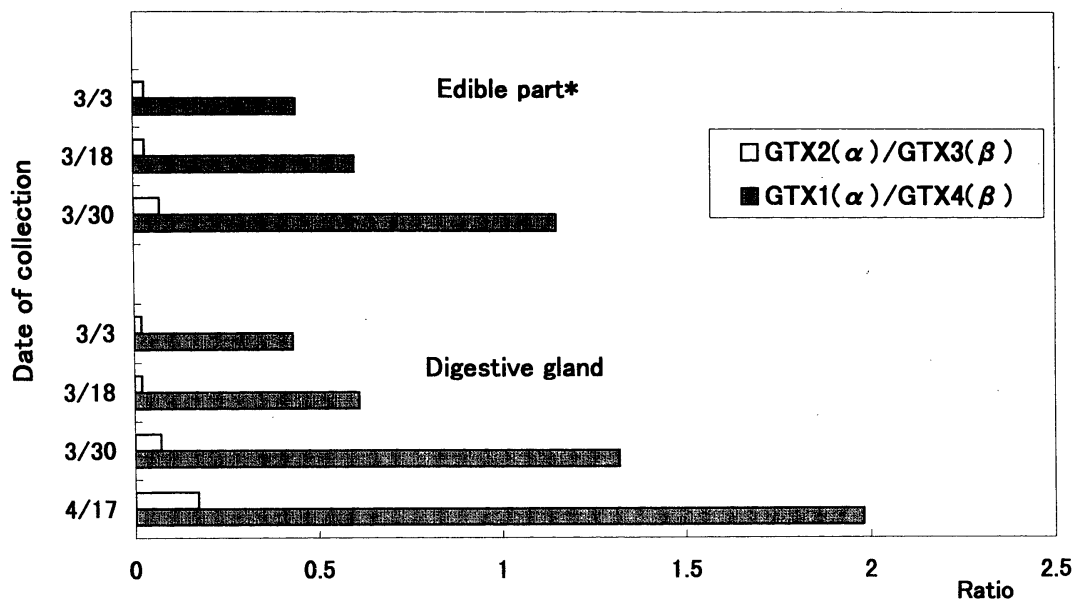

Fig. 8. Seasonal changes in $\alpha$ - to $\beta$-epimer ratio of GTXs in mussel collected in 1998 Edible part*: edible part excluding digestive gland

essentially the same mechanism; i.e., the same dinoflagellate $A$. tamarense was considered to be causative.

\section{Acknowledgment}

We thank Mr. M. Okawa and Mr. M. Fujitomi, Ibaraki Prefectural Fisheries Experimental Station for their kind assistance in collecting of bivalve specimens. We also thank the members of the Food and Drug Department of Ibaraki Prefectural Institute of Public Health for their great helpful discussions.

\section{References}

1) Noguchi, T., Kono, M., Ueda, Y., Hashimoto, K.: J. Chem. Soc. Japan 1981(5), 652-658 (1981).

2) Daigo, K., Uzu, A., Arakawa, O., Noguchi, T., Seto, H., Hashimoto, K.: Nippon Suisan Gakkaishi 51, 309-313 (1985).

3) Life Health Bureau, Ministry of Health and Welfare of Japan ed.: "Shokuhin Eisei Kensa Shishin" p. 300-305 (1991), Japan Food Hygiene Association, Tokyo.

4) Nagashima, Y., Maruyama, J., Noguchi, T., Hashimoto, K.: Nippon Suisan Gakkaishi 53, 819- 
823 (1987).

5) "Official Methods of Analysis" 15th Ed. p. 881882 (1990), AOAC, Arlington, VA.

6) Kim, C. H., Sako, Y., Ishida, Y.: Nippon Suisan
Gakkaishi 59, 641-646 (1993).

7) Oshima, Y., Bolch, C. J., Hallegraeff, G. M.: Toxicon 30, 1,539-1,544 (1992). 